\section{A matter of education}

\section{Swansea}

BRITAIN is "in danger of becoming one of the least adequately educated of all the advanced nations", according to Sir Claus Moser, president of the British Association (BA). In his address to the BA's 1990 meeting in Swansea earlier this week, Moser called for an urgent review of the whole of UK education and training, with the 1990s designated the 'decade for education'.

Moser welcomed the plan of Education Secretary John MacGregor to double UK participation in higher education over the next 25 years, noting that only 15 per cent of British school leavers now go on to higher education, compared with about half in the United States. But the expansion will need increased finance, Moser said, "of which so far there are no signs". Expansion of higher education must go hand-in-hand with $a$. broadening of courses and the encouragement of under-represented groups such as women, ethnic minorities and the poorer section of the community, he added.

Moser's views are unlikely to be received favourably by a Conservative government determined to let market forces take the lead in educational policy.

Higher education reforms are a small global warming. part of a wide-ranging review envisaged by Moser. The fact that most children leave school at the age of 16 is "the most unacceptable feature in [British] education", he said. Britain should adopt a system similar to the French Baccalauréat (a broad-based university entrance certificate), he urged. Moser also voiced concern over the quality of UK secondary school science teaching - a recent $\mathrm{BA}$ sponsored survey found that one in five British science teachers believe they lack adequate knowledge to teach their subjects. Regular 'refresher courses' are needed to improve this situation, Moser said, with salary increases to boost morale and recruitment.

Moser blamed ingrained British attitudes for the state of the country's educational system, but singled out the present government for an erosion of the social sciences in the United Kingdom. $\mathrm{He}$ argued strongly that the social disciplines are true sciences, denouncing the government's removal of the word 'science' from the title of the Economic and Social Research Council in 1983. Moser emphasized the importance of the social sciences' interaction with the 'harder' sciences in tackling problems such as

Peter Aldhous

\section{CARBON DIOXIDE SOURCE}

\section{Filing plans for algae}

\section{London}

Plans to test the avant-garde idea, first mooted in the United States, that levels of atmospheric carbon dioxide could be reduced by sowing the oceans with tons of iron filings were unveiled by a marine biologist this week at the British Association for the Advancement of Science in Swansea.

Phillip Williamson of the Natural Environment Research Council's Plymouth Marine Laboratory announced plans for a "discreet" ocean test, which will be organized jointly by the Plymouth laboratory and the University of Rhode Island. The project would be smaller than the flagship proposal from a group of US researchers, which is currently under consideration by the US National Academy of Science, to deposit about a ton of iron over some 10,000 square kilometres of sea.

Williamson is one of a growing number of researchers who believe that in principle 'fertilizing' the sea with iron filings could boost the growth of carbon-dioxide absorbing marine algae sufficiently for significant amounts of the greenhouse gas to be sucked out of the atmosphere. Their belief stems from demonstrations of ironinduced algal growth in bottled sea water.

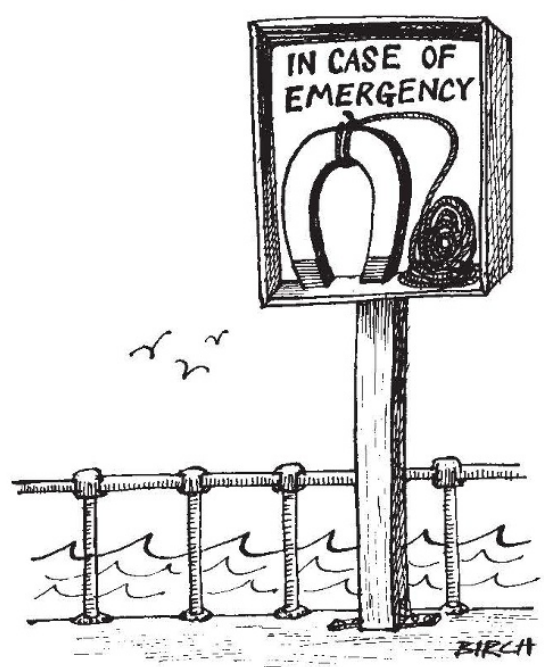

But the iron-filing idea has met with opposition from environmental groups such as Greenpeace who view it as a "bizarre technical fix" with unforeseen and potentially dangerous side effects. Its protagonists say that it is essential to find out now, whether iron filings could be used to bring down carbon dioxide levels in the event of a global warming emergency. And the only way to do that, they argue, is by conducting a small-scale test in the sea.

David Concar

\section{BIOTECHNOLOGY \\ Cetus forced into staff cuts}

\section{San Francisco}

IN what appears to portend a change in corporate strategy, Cetus, the Californiabased biotechnology company, last week announced the resignation of president and chief executive officer Robert A. Fildes and the lay-off of 100 of its 950 workers. The news comes just three weeks after the refusal by a US Food and Drug Administration (FDA) advisory panel to recommend for approval Cetus's prize cancer drug, interleukin-2 (IL-2) (see Nature 346, 501; 1990).

The company attributed Fildes's resignation on 16 August to "differing views regarding the company's priorities", which biotechnology analysts take to mean that company officials were unwilling to continue Fildes's strategy of risking much of the firm's future on the muchdelayed FDA approval of IL-2. Ronald E. Cape, who has replaced Fildes as chief executive officer, indicated that Cetus will pursue "alliances" with other companies in order to build business and reduce its risks. A spokeswoman denied that Cetus is considering selling off any parts of the company.

Announcement of how the workforce cuts will be made is expected by midSeptember. Meanwhile, company officials are still trying to schedule their next meeting with the FDA to determine what additional data on IL-2 will be required, or whether additional clinical trials are necessary, which would lead to an even longer delay. Analysts now estimate that approval of the drug will be delayed for $\mathbf{1 2}$ to 18 months.

Elizabeth Schaefer

\section{CLEAN TECHNOLOGY}

\section{Councils to cooperate}

\section{Swansea}

THE UK research councils have set up a unit to provide a focus for developing new products and processes that do not harm the environment.

The Clean Technology Unit, established by the Science and Engineering Research Council and the Agriculture and Food Research Council, will initially provide $£ 1$ million to top up 40 existing projects relevant to clean technology.

Announcing the formation of the unit at the British Association's conference in Swansea on Monday, its head Dr Nicholas Lawrence said this would rise to $£ 10 \mathrm{mil}-$ lion per year.

The first specific research projects will be announced in early 1991, and will focus on three areas: new processes that are inherently cleaner, modifications of existing processes to reduce or eliminate pollution and retrofits to deal with past pollution problems such as landfill sites.

Nuala Moran 